\title{
The Effect of Hydrolysis and Protein Source on the Efficacy of Protein Hydrolysates as Plant Resistance Inducers against Powdery Mildew
}

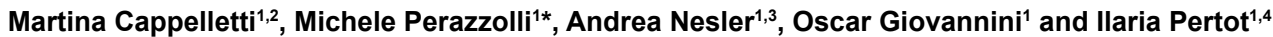

${ }^{1}$ Department of Sustainable Ecosystems and Bioresources, Research and Innovation Centre, Fondazione Edmund Mach, 38010 San Michele all'Adige, Italy ${ }^{2}$ DI4A, Department of Agrifood, Environmental and Animal Sciences, University of Udine, 33100 Udine, Italy

${ }^{3}$ Bi-PA - Biological Products for Agriculture, B-1840 Londerzeel, Belgium

${ }^{4}$ Centre Agriculture, Food and Environment, University of Trento, 38010 San Michele all'Adige, Italy

\begin{abstract}
The substitution of synthetic chemical pesticides has become a priority in agriculture and the induction of plant resistance by protein hydrolysates may offer a sustainable alternative. The protein source, method and degree of hydrolysis, as well as the amino acid and peptide composition may affect the efficacy of protein hydrolysates in protecting plants against pathogens. The aim of this work was to clarify the effect of enzymatic and acid hydrolysis on different plant protein sources (soybean, rapeseed and guar protein meal), in terms of efficacy against the powdery mildew of courgette plants (caused by Podosphaera xanthii). The enzymatic hydrolysates were obtained by incubating each protein suspension with a measured amount of Alcalase or Flavourzyme at $50^{\circ} \mathrm{C}$ for $24 \mathrm{~h}$, in order to obtain an enzyme/substrate ratio of $1 \%$ and $50 \%$. The chemical hydrolysates were obtained by acid hydrolysis using $6 \mathrm{~N} \mathrm{H}_{2} \mathrm{SO}_{4}$ at $121^{\circ} \mathrm{C}$ for $15 \mathrm{~min}(6 \mathrm{~N} \mathrm{~A})$, or at $100^{\circ} \mathrm{C}$ for $8 \mathrm{~h}(6 \mathrm{~N} \mathrm{~B})$ respectively. Preventive foliar treatments with guar hydrolysates produced with both enzymatic (Alcalase $50 \% \mathrm{E} / \mathrm{S}$ ratio) and chemical $(6 \mathrm{~N} \mathrm{~B})$ hydrolysis significantly reduced disease symptoms compared to the non-hydrolysed protein source. A positive correlation was found between efficacy and the degree of hydrolysis of guar acid hydrolysates, suggesting that the hydrolysis method may enhance the functional properties of the original protein source. In addition, positive correlations were found between the efficacy of guar hydrolysates and concentrations of specific peptides and amino acids. In conclusion, our results showed that the biocontrol effect of plant protein hydrolysates was related to the original protein source and two specific hydrolysis processes improved the functional properties of guar, producing peptide fragments and free amino acids that may be involved in the regulation of innate immune response in plants.
\end{abstract}

Keywords: Acid hydrolysis; Enzymatic hydrolysis; Biocontrol; Podosphaera xanthii; Cucurbitaceae; DAMPs

\section{Introduction}

The development of sustainable alternatives to synthetic chemicals in plant protection has become a priority in agriculture, because of increasing concerns about the negative impact of pesticides on human health and the environment [1-3]. As a response, scientists have increased efforts to find natural substances, called elicitors, that could stimulate the innate immune response in plants [4]. Indeed, plants are able to recognise and respond to specific pathogen- or microbeassociated molecular patterns (PAMPs or MAMPs), and induce pathways of triggered immunity [5], through the activation of specific surface receptors [6]. In addition, damage to plant cells by pathogens can release endogenous damage-associated molecular patterns (DAMPs) that also act as warning signals [7]. After perceiving these signals, plant cells rapidly activate a sophisticated surveillance system, by increasing the cell cytosolic $\mathrm{Ca}^{2+}$ concentration, generating reactive oxygen species and activating mitogen-activated protein kinases (MAPKs). These early signals lead to specific transcriptional and metabolic modulations, such as the expression of genes encoding pathogenesis related (PR) proteins and the synthesis of antimicrobial secondary metabolites [7]. In addition to locally restricted responses, elicitors can induce systemic resistance, which is commonly split into two groups: systemic acquired resistance (SAR), mediated by a salicylic acid-dependent process, and induced systemic resistance (ISR), which is mediated by jasmonic acid- and ethylene-sensitive pathways [8]. The origin of elicitors can be biological or synthetic [9], and they confer broad protection against multiple pathogens [10]. Among other things, protein hydrolysates and peptides from various sources can act as mediators, amplifiers or initial triggers of plant immunity, and increasing attention has been devoted to investigation of their bioactive role in plant defence [11]. Endogenous peptides generated as degradation products from precursor proteins during infection were demonstrated to act as DAMPs [12], showing a similar mode of action despite their different cellular origin [11]. Artificial protein hydrolysates are mixtures of polypeptides, oligopeptides and free amino acids obtained by hydrolysis of protein contained in agroindustrial by-products of animals (i.e., leather, viscera, feathers, blood and other animal waste) or plant origin (i.e., crop residues or seed), and enzymes and strong acids or alkalis can be alternatively employed in hydrolysis $[13,14]$. Proteolysis enhances the functional properties of the original protein, allowing activation of the latent biological activities of peptides encrypted in the protein structure [15]. The efficiency of a protein hydrolysate is linked to the type and composition of peptides generated during hydrolysis [16,17], and peptide functionalities depend on molecular size, structure and amino acid sequences [18]. The degree of hydrolysis ( $\mathrm{DH}$, the percentage of cleaved peptide bonds) is one of the main parameters used to indicate the extent of protein hydrolysis, and consequently the properties of hydrolysates $[19,20]$. Although protein

*Corresponding author: Michele Perazzolli, Research and Innovation Centre Department of Sustainable Ecosystems and Bioresources, Fondazione Edmund Mach, 38010 San Michele all'Adige, Italy, Tel: +390461615411; E-mail: michele.perazzolli@fmach.it

Received June 16, 2017; Accepted June 24, 2017; Published August 26, 2017

Citation: Cappelletti M, Perazzolli M, Nesler A, Giovannini O, Pertot I (2017) The Effect of Hydrolysis and Protein Source on the Efficacy of Protein Hydrolysates as Plant Resistance Inducers against Powdery Mildew. J Bioprocess Biotech 7: 306. doi:10.4172/2155-9821.1000306

Copyright: ( 2017 Cappelletti M, et al. This is an open-access article distributed under the terms of the Creative Commons Attribution License, which permits unrestricted use, distribution, and reproduction in any medium, provided the original author and source are credited. 
hydrolysates are commonly applied in small quantities, bioactive amino acids and peptide fragments can be readily absorbed by plants through diffusion processes and easily reach active sites [21]. Foliar applications of protein hydrolysates produce biostimulant effects on crops, especially under stress-inducing environmental conditions [22]. In particular, they could enhance the activity of the antioxidant system and boost plant metabolism, thus increasing root and shoot growth and promoting the productivity and fruit quality of several crops [14,23]. Moreover, peptide fragments can act as inducers of innate plant immunity. For example, casein and soybean hydrolysates have been shown to elicit grapevine defence mechanisms against downy mildew and grey mould by the up-regulation of PR genes [24,25]. Likewise, a protein derivative was effective in controlling courgette powdery mildew and grapevine [26], and activated the expression of defence-related genes in grapevine, suggesting the stimulation of plant resistance mechanisms [27]. In addition, the characteristics and functional properties of hydrolysates are influenced by the method used for hydrolysis and by the choice of the original protein source [28]. Despite significant economic benefits, chemical hydrolysis presents several disadvantages compared to the enzymatic process $[14,29]$, such as the increased salinity of the final product. Moreover, animal-derived hydrolysates have frequently been demonstrated to have negative effects on plant growth [30,31], while plant-derived protein hydrolysates have been shown to act as non-toxic signalling molecules for plant defence, growth and development [32]. Accordingly, plant-derived protein hydrolysates generated by agroindustrial by-products may represent a low-cost organic strategy against crop diseases, considering their potential biocontrol properties and their harmless origin. Furthermore, they could become a sustainable solution to the inconvenience of industrial waste disposal, making their production interesting from environmental and economic points of view [28]. Among others, soybean (Glycine max L., Fabaceae family), rapeseed (Brassica campestris L., Brassicaceae family) and guar (Cyamopsis tetragonoloba L., Fabaceae family) meals are currently used for animal feed. They have high protein concentrations (30-45\%) and well-balanced amino acid profiles [33-35], and they are available at competitive prices as compared to other protein sources [36]. More specifically, soybean and rapeseed meals are agro-industrial waste byproducts obtained from the solvent extraction of oil [33-35], and guar meal is a by-product of guar-gum extraction, which originates from its seeds, containing a gelling agent [34].

In this study, courgettes (Cucurbita pepo L.) and powdery mildew caused by Podosphaera xanthii [(Castagne) U. Braun and N. Shishkoff; Podosphaera fusca (Castagne) U. Braun and N. Shishkoff] were selected as the study pathosystem, because they are both economically significant and easy to handle in an experimental set-up [37]. In addition, systemic resistance against powdery mildew in cucurbits is easy to induce with several compounds, such as oxalate or phosphate salts [38-40] and oligochitosans or oligopectates [41]. The aim of this work was to compare the effect of acid and enzymatic hydrolysis of soybean, rapeseed and guar meal in terms of biocontrol efficacy against courgette powdery mildew under greenhouse conditions, and to investigate the potential contribution of amino acids and peptide fragments generated during hydrolysis to the activation of plant resistance.

\section{Materials and Methods}

\section{Production of protein hydrolysates}

The raw materials used as a protein source were industrial soybean and guar meal ( $45 \%$ and $35 \%$ protein content, respectively) and rapeseed pellets (32\% protein content), provided by Zebele Srl (Padua, Italy). Each product was milled to a powder using a jug blender (JB 5050, Braun, Kronberg im Taunus, Germany) before hydrolysis. As described in previous studies [18,42-44], the enzymatic hydrolysates were obtained with two commercial proteolytic enzymes, namely Alcalase $2.4 \mathrm{~L}$ (Sigma-Aldrich, St. Louis, MO, USA) and Flavourzyme 500 L (SigmaAldrich), which are widely used for protein hydrolysis in industrial and research applications [45]. Specifically, Alcalase (a non-specific microbial protease of Bacillus licheniformis with endopeptidase activity) has a density of $1.25 \mathrm{~g} / \mathrm{ml}$ and a specific activity of 2.4 Anson Units (AU) per gram, while Flavourzyme (a protease complex of Aspergillus oryzae with endo- and exoprotease activities) has a density of $1.10-1.30 \mathrm{~g} / \mathrm{ml}$ and a specific activity of 500 Leucine Aminopeptidase Units (LAPU) per gram. For each protein source (soybean, rapeseed and guar), $20 \mathrm{~g}$ of powder were mixed with $100 \mathrm{ml}$ of distilled water and pasteurised at $85^{\circ} \mathrm{C}$ for $5 \mathrm{~min}$. After cooling down to $50^{\circ} \mathrm{C}$, the $\mathrm{pH}$ was adjusted to the manufacturer's recommended values for each specific protease ( $\mathrm{pH} 8$ for Alcalase and $\mathrm{pH}$ 6.5-7 for Flavourzyme respectively) with $10 \mathrm{~N} \mathrm{KOH}$. Subsequently, each protein suspension was treated with a measured amount of Alcalase or Flavourzyme, in order to obtain an enzyme/ substrate ratio (E/S ratio) of $1 \%$ and $50 \%$ (enzyme unit/protein weight), based on the protein content of the protein source [18]. Digestion was carried out through incubation at $50^{\circ} \mathrm{C}$ for $24 \mathrm{~h}$ in a $500 \mathrm{ml}$-flask under orbital shaking at $200 \mathrm{rpm}$. After inactivating the enzymes by heating at $85^{\circ} \mathrm{C}$ for $5 \mathrm{~min}$, the undigested proteins and insoluble particulates were discarded as a pellet after centrifugation at 3,800 $\times \mathrm{g}$ for $20 \mathrm{~min}$. Finally, the $\mathrm{pH}$ was adjusted to $\mathrm{pH} 7$ with $10 \mathrm{~N} \mathrm{KOH}$ and hydrolysates were kept at $-20^{\circ} \mathrm{C}$ until analysis. The acid hydrolysates were produced according to the method described by Aaslyng et al. [46], with some modifications. For each protein source (soybean, rapeseed and guar), 20 $\mathrm{g}$ of powder were mixed with $100 \mathrm{ml}$ of $6 \mathrm{~N}$ sulphuric acid $\left(\mathrm{H}_{2} \mathrm{SO}_{4}\right)$, and treated in glass bottles for $15 \mathrm{~min}$ at $121^{\circ} \mathrm{C}(6 \mathrm{~N} \mathrm{~A})$ or for $8 \mathrm{~h}$ at $100^{\circ} \mathrm{C}$ $(6 \mathrm{~N} \mathrm{~B})$, respectively. After cooling at room temperature, the mixtures were neutralised to $\mathrm{pH} 7$ with $10 \mathrm{~N} \mathrm{KOH}$, centrifuged for 20 min at $3,800 \times \mathrm{g}$, and the pellet was discarded to remove insoluble particulates. The centrifuged samples were stored at $-20^{\circ} \mathrm{C}$ until analysis. In order to obtain an hydrolysate that could be effectively used in agriculture, the method of Aaslyng et al. [46], which uses hydrochloric acid $(\mathrm{HCl})$ and sodium hydroxide $(\mathrm{NaOH})$ for neutralisation, thus obtaining sodium chloride $(\mathrm{NaCl})$ as the final salt, was partially modified, because $\mathrm{NaCl}$ has a phytotoxic effect on plant leaves. Specifically, we used $\mathrm{H}_{2} \mathrm{SO}_{4}$ and neutralised it with $\mathrm{KOH}$, leading to the production of potassium sulphate $\left(\mathrm{K}_{2} \mathrm{SO}_{4}\right)$, which is a common fertiliser [47].

\section{Determination of the degree of hydrolysis}

The degree of hydrolysis (DH) is defined as the percentage of cleaved peptide bonds according to the following equation:

$$
\mathrm{DH}=h / h_{\text {tot }} \times 100 \%
$$

where $h$ is the number of hydrolysed bonds, and $h_{\text {tot }}$ is the total number of peptide bonds per protein equivalent [48]. The degree of hydrolysis was calculated using the $o$-phthaldialdehyde (OPA) method, as first described by Church et al. [49], which is based on the reaction between amino groups released during hydrolysis and $o$-phthaldialdehyde, in the presence of dithiothreitol (DTT, ThermoFisher Scientific, Waltham, MA, USA), forming a compound detectable at $340 \mathrm{~nm}$ in a spectrophotometer (Ultrospec 3100, Amersham Bioscience, Little Chalfont, UK). In particular, the OPA solution was prepared according to Nielsen et al. [48], as follows. Firstly, $7.62 \mathrm{~g}$ di-Na-tetraborate decahydrate (SigmaAldrich) and $200 \mathrm{mg} \mathrm{Na}$-dodecyl-sulphate were completely dissolved in $150 \mathrm{ml}$ of deionised water. At the same time, $160 \mathrm{mg}$ OPA (Sigma- 
Aldrich) was dissolved in $4 \mathrm{ml}$ of ethanol (Sigma-Aldrich) and this was then added to the aforementioned solution. Finally, $176 \mathrm{mg}$ of DTT were added, and the final OPA solution was made up to $200 \mathrm{ml}$ with deionised water. Serine was chosen as the standard, since in reactions it shows a response very close to the average response of other amino acids [48], and the standard solution was prepared as follows: $50 \mathrm{mg}$ L-serine (Sigma-Aldrich, St. Louis, MO, USA) was diluted in $500 \mathrm{ml}$ of deionised water $(0.9516$ meqv/l). After preparing all the reagents, $3 \mathrm{ml}$ of OPA solution were added to all the test tubes. For standard, blank and sample optical density (OD) measurements with a spectrophotometer (Ultrospec 3100), $400 \mu \mathrm{l}$ of serine standard, deionised water or each protein hydrolysate were added to the test tubes respectively. To estimate $\mathrm{DH}$, determination of $h$ in the OPA method was calculated according to Nielsen et al. [48], with the following equation:

Serine $-\mathrm{NH}_{2}=\left(\mathrm{OD}_{\text {sample }}-\mathrm{OD}_{\text {blank }}\right) /\left(\mathrm{OD}_{\text {standard }}-\mathrm{OD}_{\text {blank }}\right) \times 0.9516 \mathrm{meqv} / \mathrm{l}$ $\times \mathrm{V} \times 100 / \mathrm{X} \times \mathrm{P}$

where serine- $\mathrm{NH}_{2}$ is meqv serine $\mathrm{NH}_{2} / g$ protein, $\mathrm{OD}$ is the optical density of the sample, $\mathrm{V}$ is the sample volume (in litres), $\mathrm{X}$ is the sample dry weight (in grams) and $\mathrm{P}$ is the protein content (as a percentage) in the sample.

The expression for $h$, defined by Adler-Nissen [50] as the concentration of protein in amino groups formed during hydrolysis, in milliequivalents (meqv)/g, was then calculated as:

\section{$h=\left(\right.$ serine $\left.-\mathrm{NH}_{2}-\beta\right) / \alpha$ meqv/g protein}

where the values reported by Adler-Nissen [50] were used for $B$ $(=0.4)$ and $\alpha(=1)$.

The value of $h_{\text {tot }}$, defined as hydrolysis equivalent at complete hydrolysis to amino acids, was calculated by summing the content of the individual amino acids in $1 \mathrm{~g}$ of protein [50], and fixed to $8 \mathrm{~g}$ equivalent/ $\mathrm{kg}$ protein, because for most proteins the average molecular weight of amino acids is $125 \mathrm{~g} / \mathrm{mol}$ [48].

\section{Protein concentration and peptide and amino acid composition analysis}

The protein concentration of hydrolysates was determined by measuring the $\mathrm{OD}$ of the samples at $205 \mathrm{~nm}\left(A_{205}\right)$ in the spectrophotometer, as described by Simonian [51]. In particular, a calibration curve prepared with standard solutions of bovine serum albumin (BSA, Sigma-Aldrich) was used to calculate the protein concentration of each sample. The identification of peptides and amino acids was performed on hydrolysed and non-hydrolysed samples by an external service company (ISB Srl, Ion Source and Biotechnologies, Milan, IT). Briefly, chromatographic runs were obtained using an Ultimate 3000 HPLC (Thermofisher, San Jose, USA) combined with HCT ultra mass spectrometer (Bruker Daltonics, Breme, Germany). The samples were diluted 1:10 in HPLC grade water, and injected for LC-MS/ MS analysis. Mobile phases A and B were composed of $0.2 \%$ formic acid and acetonitrile $\left(\mathrm{CH}_{3} \mathrm{CN}\right)$ respectively. The column was a Phenomenex Luna C18 $(2.0 \times 50 \mathrm{~mm}$, particle size $3 \mu \mathrm{m})$, and the volume of injection was $15 \mu \mathrm{l}$. Peptide annotation was obtained using the plant GPM database (http://plant.thegpm.org/tandem/thegpm_tandem.html), with specific searches in G. max, B. napus and Viridiplantae proteomes for soybean, rapeseed and guar samples respectively. Based on peptide peak areas, the peptides identified in hydrolysed samples were compared with those found in non-hydrolysed ones, and quantitation ratios were calculated for similar peptides (sequence identity higher than 70\%). The free amino acid content was quantified $(\mu \mathrm{g} / \mathrm{mL}$ ) by ISB Srl (Ion Source and Biotechnologies, Milan, IT) using liquid chromatography coupled with mass spectrometry for quantification.

\section{Evaluation of the efficacy of protein hydrolysates against courgette powdery mildew under greenhouse conditions}

Enzymatic and acid protein hydrolysates were tested against powdery mildew on courgette plants (cv Nero Milano) at a dosage of $1 \mathrm{~g} / \mathrm{l}$, in two and three independent experiments respectively. Briefly, courgette plants were grown in individual 2.5 l-pots containing a mixture of peat and pumice (3:1), as described by Nesler et al. [26]. In all the experiments, plants were grown in a greenhouse at $25 \pm 1^{\circ} \mathrm{C}$ (day and night), with $65 \pm 5 \%$ relative humidity (RH) and a $14 \mathrm{~h}$ photoperiod. On plants with two fully developed leaves, both surfaces of each leaf were treated with a hand sprayer, allowed to dry, and inoculated with a water suspension of $P$. xanthii conidia $\left(1 \times 10^{5} \mathrm{conidia} / \mathrm{ml}\right)$. The inoculum was obtained from infected leaves of untreated courgette plants, and was maintained by subsequent inoculations under greenhouse conditions at $25 \pm 1^{\circ} \mathrm{C}$ with $80 \pm 10 \% \mathrm{RH}$. As a control, plant leaves were sprayed with water and with non-hydrolysed protein sources, in order to detect a possible effect of the original protein sources against the pathogen. In particular, for the enzymatic process the non-hydrolysed sample followed the hydrolysis steps without the addition of any enzyme, while for the acid process the original plant sources were subjected to the hydrolysis procedure, but replacing sulphuric acid with deionised water. As an additional control for acid hydrolysis, courgette leaves were treated with a $0.11 \mathrm{M} \mathrm{K}_{2} \mathrm{SO}_{4}$ solution, corresponding to the highest quantity of the salt created in the final hydrolysates. Four replicates (plants) were analysed for each treatment, and powdery mildew severity was scored at 14 days post-inoculation (dpi) on all leaves by assessing the percentage of infected leaf area covered by white powdery mildew sporulation, according to the standard guidelines of the European and Mediterranean Plant Protection Organization [52]. The efficacy of each treatment was calculated according to the following formula:

Efficacy $=(S C-S T) / S C \times 100$

where SC is the disease severity of water-treated plants (control) and ST is the disease severity of plants treated with a tested molecule.

\section{Evaluation of direct effect on the germination of Podosphaera xanthii conidia}

The effect of enzymatic and acid protein hydrolysates on $P$. xanthii conidial germination was analysed following the method previously described by Romero et al. [53], with some modifications. Healthy courgette plants were grown for four weeks under greenhouse conditions. Leaves were surface sterilised by incubation in $0.5 \%$ hypochlorite for $5 \mathrm{~min}$, and rinsed three times in sterile water for $5 \mathrm{~min}$ under orbital shaking at $80 \mathrm{rpm}$. Leaf disks ( $19 \mathrm{~mm}$ diameter) were cut out and placed (adaxial surface uppermost) on wet sterilised filter paper (three foils) in Petri dishes, and then homogenously sprayed with enzymatic and acid hydrolysates at a dosage of $1 \mathrm{~g} / \mathrm{l}$ using a small hand sprayer. As a control, leaf discs were sprayed with water and non-hydrolysed protein sources. For acid hydrolysates, a $0.11 \mathrm{M} \mathrm{K}_{2} \mathrm{SO}_{4}$ solution was also tested as an additional control. Leaf disks were then dried under a laminar hood for $1 \mathrm{~h}$, and conidia from young leaves carrying fresh sporulation of $P$. xanthii at 14 dpi were brushed gently with a paint brush. Plates were incubated for $48 \mathrm{~h}$ at $23 \pm 1{ }^{\circ} \mathrm{C}$ with a $\mathrm{RH}$ of $99 \%$ and a $16 \mathrm{~h}$ photoperiod to allow conidia germination. Conidia were removed from the leaf disc surface using a piece of transparent adhesive tape $(2 \times 3 \mathrm{~cm})$, and stained with a drop of Cotton Blue staining solution, according to Peries [54]. The percentage of germinated conidia was assessed by counting under a light microscope (Eclipse 80i, Nikon, Amsterdam, the Netherlands), 
Citation: Cappelletti M, Perazzolli M, Nesler A, Giovannini O, Pertot I (2017) The Effect of Hydrolysis and Protein Source on the Efficacy of Protein Hydrolysates as Plant Resistance Inducers against Powdery Mildew. J Bioprocess Biotech 7: 306. doi:10.4172/2155-9821.1000306

Page 4 of 10

and conidia were scored as germinated when their germ tube length was greater than their lateral radius [55]. Two replicates of three disks were assessed for each treatment, by counting 30 conidia for each leaf disk.

\section{Statistical analysis}

Data were analysed with Statistica 13.1 software (Dell, Round Rock, TX, USA). An F-test was used to demonstrate the non-significant effect of experiments $(p>0.05)$, before pooling the data. After validation of normal distribution (K-S test, $p>0.05$ ) and variance homogeneity (Cochran's test, $p>0.05$ ) of the data, analysis of variance (ANOVA) was carried out, and Fisher's LSD test $(p \leq 0.05)$ was applied to detect significant differences between treatments. Amino acid and peptide composition data for hydrolysed and non-hydrolysed samples were plotted using Principal Component Analysis (PCA) with Statistica 13.1 software. Pearson's analysis $(p \leq 0.05)$, performed on all replicates (potted plants), was used to reveal potential correlations between efficacy levels and the compositional data of hydrolysates, such as $\mathrm{DH}$ values, concentrations of detected free amino acids and the quantitation ratios of detected peptides, in order to reveal the properties of different hydrolysis methods. The percentage of identity between different peptide sequences was obtained using BLAST pairwise alignment of protein sequences.

\section{Results}

\section{Evaluation of the efficacy of enzymatic and acid hydrolysates against courgette powdery mildew}

Soybean, rapeseed and guar enzymatic hydrolysates produced using Alcalase and Flavourzyme at two different E/S ratios (1\% and 50\%) were tested against powdery mildew on courgette plants (Figure 1). Foliar treatments with soybean and rapeseed enzymatic hydrolysates demonstrated an efficacy in disease reduction comparable to treatments with the non-hydrolysed protein source (Figures $1 \mathrm{~A}$ and 1B). Conversely, the efficacy against powdery mildew was higher after the application of the guar hydrolysate produced with Alcalase at $50 \%$, as compared to the non-hydrolysed protein source (Figure 1C). No direct effect on $P$. xanthii conidia germination was observed after application of guar enzymatic hydrolysates produced with Alcalase (40.5 $\pm 12.4 \%$ and $35 \pm 8.8 \%$ respectively) and Flavourzyme (36.3 $\pm 5.4 \%$ and 31.1 $\pm 7.4 \%$, respectively) at $1 \%$ and $50 \%$ as compared with $\mathrm{H}_{2} \mathrm{O}$-treated leaf disks (62.8 $\pm 4.2 \%$; ANOVA, $p>0.05$; Fisher's LSD test). Similarly, conidia germination was not affected by treatments with soybean enzymatic hydrolysates produced with Alcalase $(28.3 \pm 5.3 \%$ and 48.9 $\pm 1.4 \%$, respectively) and Flavourzyme $(30.6 \pm 4.7 \%$ and $36.1 \pm 5.7 \%$, respectively), and with rapeseed enzymatic hydrolysates produced with Alcalase (30.6 $\pm 4.5 \%$ and $37.8 \pm 4.4 \%$, respectively) and Flavourzyme (32.8 $\pm 6.3 \%$ and $34.4 \pm 4.1 \%$, respectively) at $1 \%$ and $50 \% \mathrm{E} / \mathrm{S}$ ratio, as compared with $\mathrm{H}_{2} \mathrm{O}$-treated leaf disks $(52.2 \pm 3.2 \%$; ANOVA, $p>0.05$; Fisher's LSD test).

Soybean, rapeseed and guar acid hydrolysates obtained using $6 \mathrm{~N}$ $\mathrm{H}_{2} \mathrm{SO}_{4}$ with two different time and temperature conditions were tested against courgette powdery mildew (Figure 2). Foliar treatments with soybean and rapeseed acid hydrolysates showed an efficacy in disease reduction comparable to that obtained with $\mathrm{K}_{2} \mathrm{SO}_{4}$ and non-hydrolysed protein sources (Figures $2 \mathrm{~A}$ and $2 \mathrm{~B}$ ). In contrast, the efficacy against powdery mildew was significantly higher after application of the guar hydrolysate produced with $6 \mathrm{~N} \mathrm{H}_{2} \mathrm{SO}_{4}$ at $100{ }^{\circ} \mathrm{C}$ for $8 \mathrm{~h}(6 \mathrm{~N} \mathrm{~B})$, as compared to $\mathrm{K}_{2} \mathrm{SO}_{4}$ and the non-hydrolysed protein source (Figure 2C). The estimated contribution of $\mathrm{K}_{2} \mathrm{SO}_{4}$ and hydrolysed proteins to the control of powdery mildew symptoms is presented separately, with green and red bars respectively (Figure 2). In detail, $\mathrm{K}_{2} \mathrm{SO}_{4}$ contributed to disease reduction with a mean efficacy of $39.5 \pm 4.6 \%$, whereas the additional effect of hydrolysed peptides and free amino acids ranged from $11.5 \pm 2.2 \%$ to $17.5 \pm 3.9 \%$, from $0.8 \pm 4.4 \%$ to $18.5 \pm 2.5 \%$ and from $10.5 \pm 2.8 \%$ to $28.9 \pm 2.1 \%$ for soybean, rapeseed and guar $6 \mathrm{~N}$ A and $6 \mathrm{~N}$ B hydrolysates, respectively. More specifically, the levels of
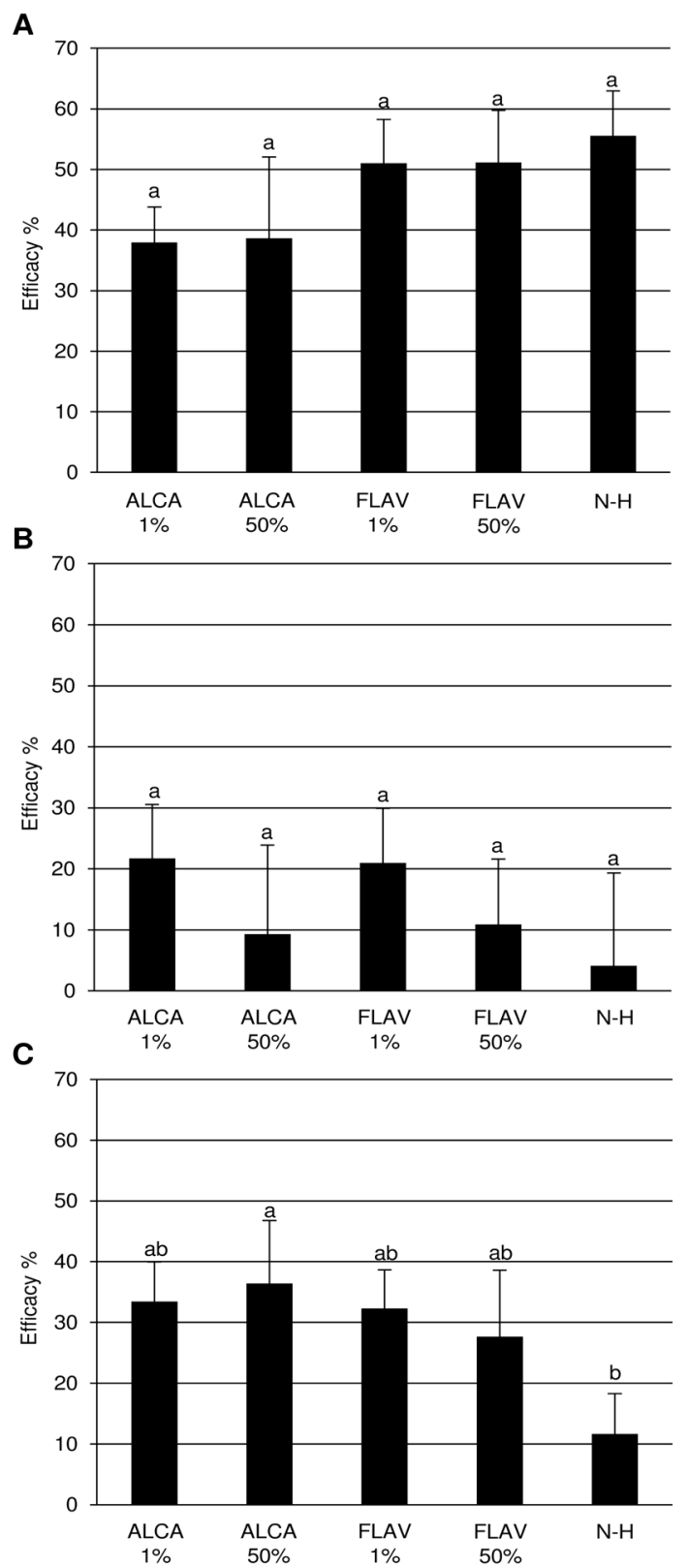

Figure 1: Effect of soybean $(A)$, rapeseed $(B)$ and guar $(C)$ enzymatic hydrolysates against courgette powdery mildew under greenhouse conditions. Efficacy against powdery mildew (percentage) was evaluated on courgette plants treated with hydrolysed and non-hydrolysed $(\mathrm{N}-\mathrm{H})$ protein sources as compared to watertreated plants. Enzymatic hydrolysates were obtained using Alcalase (ALCA) and Flavourzyme (FLAV) at a dosage of $1 \%$ (ALCA $1 \%$ and FLAV $1 \%$, respectively) and $50 \%$ of the protein content (ALCA $50 \%$ and FLAV $50 \%$, respectively). An $F$-test revealed non-significant differences between two independent experiments $(p>0.05)$, and data were pooled. The mean efficacy and standard error values of eight replicates (potted plants) in two experiments are presented for each treatment. Different letters indicate significant differences between treatments according to Fisher's LSD test. 
A

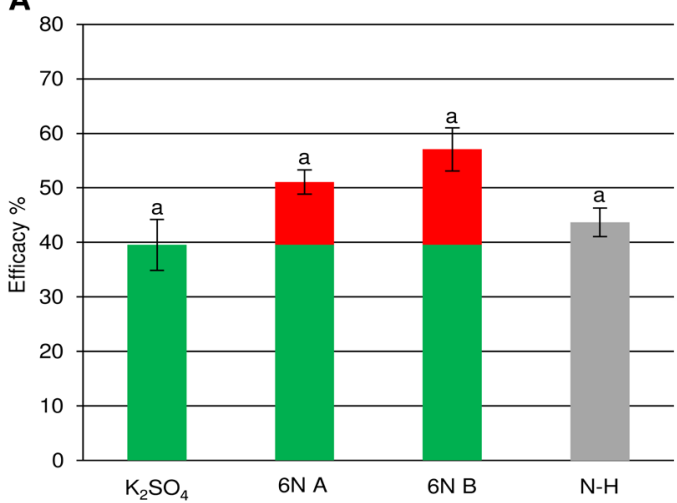

B

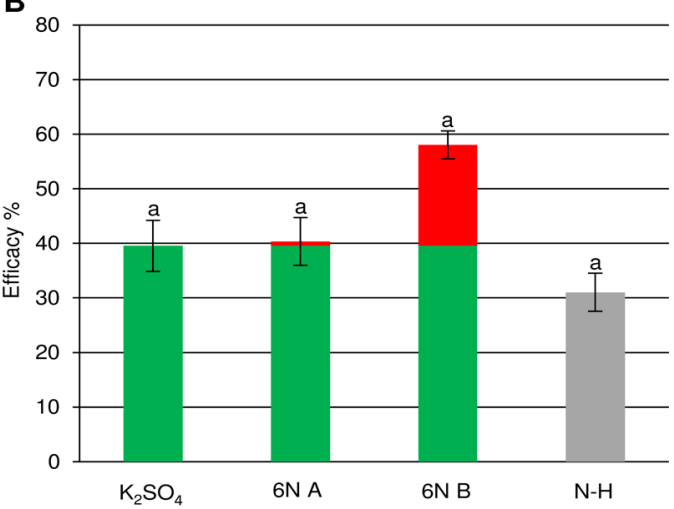

C

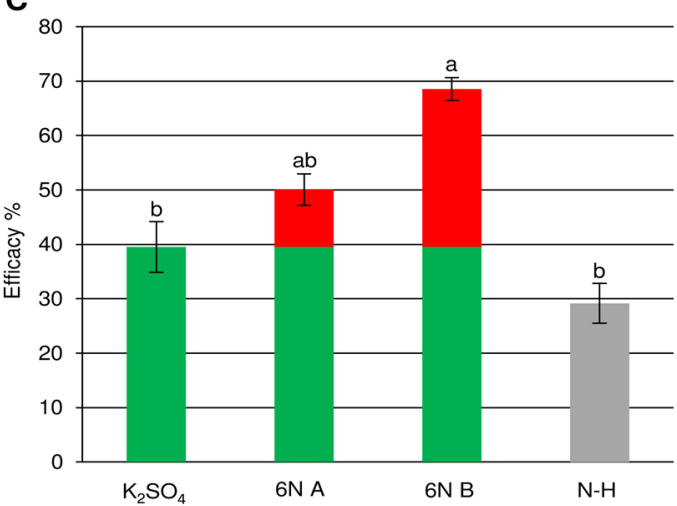

Figure 2: Effect of soybean $(A)$, rapeseed $(B)$ and guar $(C)$ acid hydrolysates against courgette powdery mildew under greenhouse conditions. Efficacy against powdery mildew (percentage) was evaluated on courgette plants treated with hydrolysed and non-hydrolysed $(\mathrm{N}-\mathrm{H})$ protein sources or with $0.11 \mathrm{M} \mathrm{K}_{2} \mathrm{SO}_{4}$ as compared to water-treated plants. Acid hydrolysates were obtained by incubation of the protein source with $6 \mathrm{~N} \mathrm{H}_{2} \mathrm{SO}_{4}$ at $121^{\circ} \mathrm{C}$ for $15 \min (6 \mathrm{~N} \mathrm{~A})$ and at $100^{\circ} \mathrm{C}$ for $8 \mathrm{~h}(6 \mathrm{~N} \mathrm{~B})$. An F-test revealed non-significant differences between three independent experiments ( $p>0.05)$, and data were pooled. Mean efficacy and standard error values of 12 replicates (potted plants) in three experiments are presented for each treatment. Different letters indicate significant differences between treatments according to Fisher's LSD test. For each hydrolysate, the contribution of $\mathrm{K}_{2} \mathrm{SO}_{4}$ and hydrolysed proteins to the efficacy in disease reduction was visually presented using green and red bars respectively.

efficacy considered without the contribution of $\mathrm{K}_{2} \mathrm{SO}_{4}$ are shown in Figure S1 of the Supplementary File, and reveal the potential impact of hydrolysed proteins alone, confirming the higher efficacy of the guar acid hydrolysate $\mathrm{H}_{2} \mathrm{SO}_{4}, 6 \mathrm{~N}$ B. The percentage of conidia germination on guar $6 \mathrm{~N}$ A- and $6 \mathrm{~N}$ B-treated leaf disks $(12.8 \pm 2.9 \%$ and $18.3 \pm$ $2.8 \%$, respectively) was comparable (ANOVA, $p>0.05$; Fisher's LSD test) to that on $\mathrm{K}_{2} \mathrm{SO}_{4}$-treated leaves $(20 \pm 5.4 \%)$, and significantly lower as compared with $\mathrm{H}_{2} \mathrm{O}$-treated leaf disks $(52.2 \pm 3.2 \%$, ANOVA, $p \leq$ 0.05; Fisher's LSD test). Similar results were obtained for soybean and rapeseed acid hydrolysates (data not shown).

\section{Composition of enzymatic and acid hydrolysates}

No significant Pearson's correlations $(p>0.05)$ were detected between the efficacy and $\mathrm{DH}$ values of enzymatic hydrolysates for all protein sources (Table 1). In contrast, a positive correlation $\left(\mathrm{R}^{2}=0.41 ; p=0.048\right)$ was found for guar acid hydrolysates (Table 1$)$, while no significant correlation emerged for soybean and rapeseed acid hydrolysates. In order to better understand the modes of action of protein hydrolysates, the content of peptides (Tables S1, S2 and S3) and free amino acids (Tables S4, S5 and S6) present in soybean, rapeseed and guar samples was analysed. The peptide composition varied according to the hydrolysis protocol for each protein source, and PCA analysis mostly discriminated samples of enzymatic hydrolysis (Figure 3). Specifically, differences in peptide composition were mainly observed between Alcalase 1\%, Flavourzyme $1 \%$ and $50 \%$ hydrolysates of soybean and rapeseed protein sources (Figures $3 \mathrm{~A}$ and 3B), and between Flavourzyme 50\%, Alcalase $1 \%$ and $50 \%$ hydrolysates of the guar protein source (Figure 3C). On the other hand, the nonhydrolysed sample clustered with $6 \mathrm{~N} \mathrm{~A}$ and $6 \mathrm{~N} \mathrm{~B}$ acid hydrolysates for each protein source. Pearson's correlation analysis between the efficacy against powdery mildew and peptide quantitation ratios in guar hydrolysates revealed a moderate negative correlation for one peptide of enzymatic hydrolysates (Peptide 1; Table 2). Moreover, positive and negative correlations respectively were observed for two (Peptide 2 and Peptide 5) and one (Peptide 3) peptides for acid hydrolysates (Table 2). Correlation analysis of peptide composition data was not performed for soybean and rapeseed samples, since these hydrolysates were not effective against courgette powdery mildew.

PCA analysis of amino acid composition discriminated $6 \mathrm{~N}$ A and $6 \mathrm{~N} \mathrm{~B}$ acid hydrolysates on the first axis and Alcalase $1 \%$ and $50 \%$ hydrolysates on the second axis for each protein source (Figure 4). Moreover, non-hydrolysed samples clustered with Flavourzyme $1 \%$ and $50 \%$ hydrolysates. As regards guar samples, hydrolysates with significant efficacy against courgette powdery mildew (namely Alcalase $50 \%$ and $6 \mathrm{~N}$ B samples) clustered with PCA analysis (Figure 4C). Pearson's correlation analysis between the efficacy against powdery mildew and amino acid concentrations detected a positive correlation for DLHomophenylalanine and L-Glutamine of guar enzymatic hydrolysates, and for all amino acids of guar acid hydrolysates, except for L-Leucine/ Isoleucine, L-Aspartic acid and L-Methionine (Table 3). Pearson's

\begin{tabular}{|c|c|c|c|}
\hline Treatment & $\begin{array}{c}\text { Protein } \\
\text { sources }\end{array}$ & $\mathbf{R}^{2}$ value & p-value \\
\hline Enzymatic hydrolysates & Soybean & -0.289 & NS \\
\hline & Rapeseed & -0.069 & NS \\
\hline & Guar & 0.009 & NS \\
\hline Acid hydrolysates & Soybean & -0.226 & NS \\
\hline & Rapeseed & 0.156 & NS \\
\hline & Guar & 0.408 & 0.048 \\
\hline
\end{tabular}

Pearson's correlation analysis between efficacy values (\%) against powdery mildew and degree of hydrolysis (DH) values (\%) of enzymatic and acid hydrolysates of soybean, rapeseed and guar was performed on all replicates (plotted plants) Correlation $\left(\mathrm{R}^{2}\right.$ value) and significant $(p$-value $\leq 0.05)$ or non-significant (NS) values were calculated.

Table 1: Pearson's correlation between the efficacy against powdery mildew and the degree of hydrolysis of enzymatic and acid hydrolysates. 

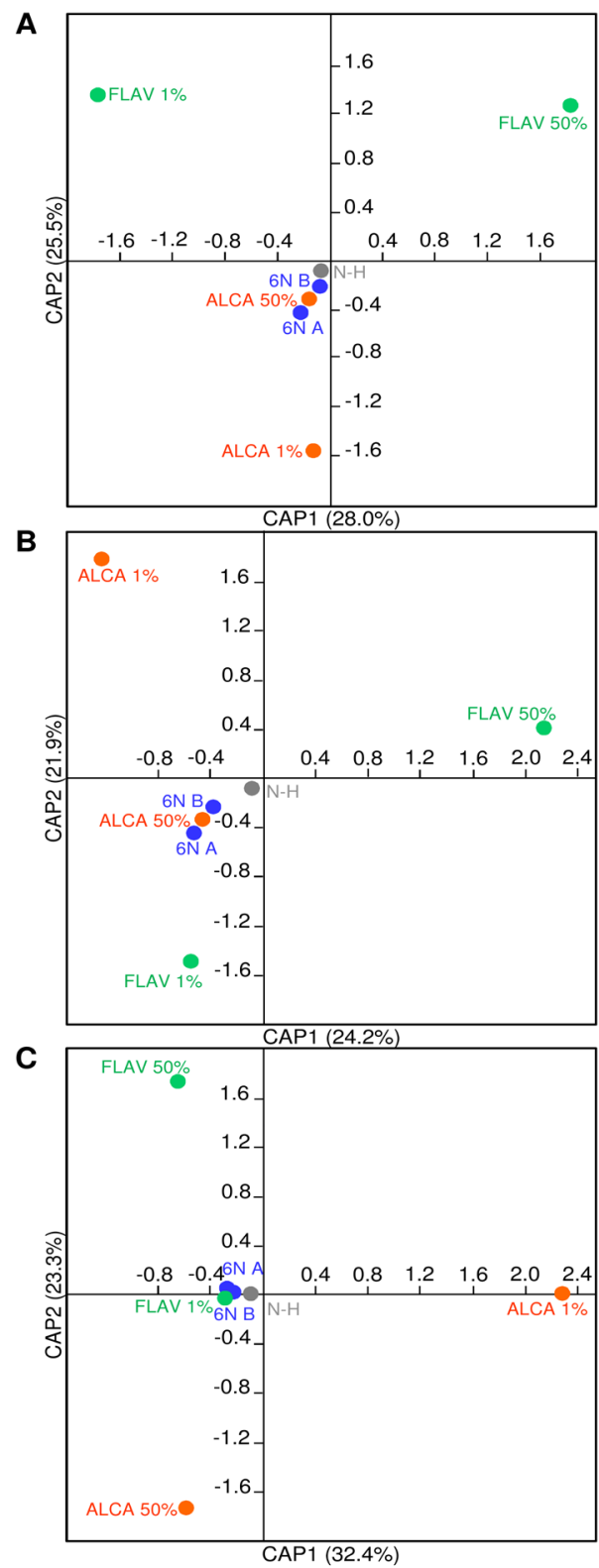

Figure 3: Principal component analysis (PCA) of hydrolysed samples according to their amino acid composition. PCA was obtained for soybean (A), rapeseed $(C)$ and guar $(\mathrm{C})$ samples using data for non-hydrolysed samples $(\mathrm{N}-\mathrm{H}$; grey), acid hydrolysates (blue) obtained by incubation with $6 \mathrm{~N} \mathrm{H}_{2} \mathrm{SO}_{4}$ at $121^{\circ} \mathrm{C}$ for $15 \mathrm{~min}(6 \mathrm{~N}$ A) or at $100^{\circ} \mathrm{C}$ for $8 \mathrm{~h}(6 \mathrm{~N} \mathrm{~B})$, and enzymatic hydrolysates obtained using Alcalase (ALCA, orange) and Flavourzyme (FLAV, green) at a dosage of $1 \%$ (ALCA $1 \%$ and FLAV $1 \%$, respectively) or $50 \%$ of the protein content (ALCA $50 \%$ and FLAV $50 \%$ respectively). The two first principal components are plotted with the proportion of variance explained by each component in brackets.

analysis performed on soybean enzymatic and acid hydrolysates revealed no significant correlation between efficacy levels and amino acid concentrations (Table S7), as in the case of rapeseed enzymatic hydrolysates (Table S8). On the other hand, 14 positive correlations were found between efficacy levels and the amino acid concentrations of rapeseed acid hydrolysates (Table S8).

\section{Discussion}

Protein-derived DAMPs resulting from pathogen infection were
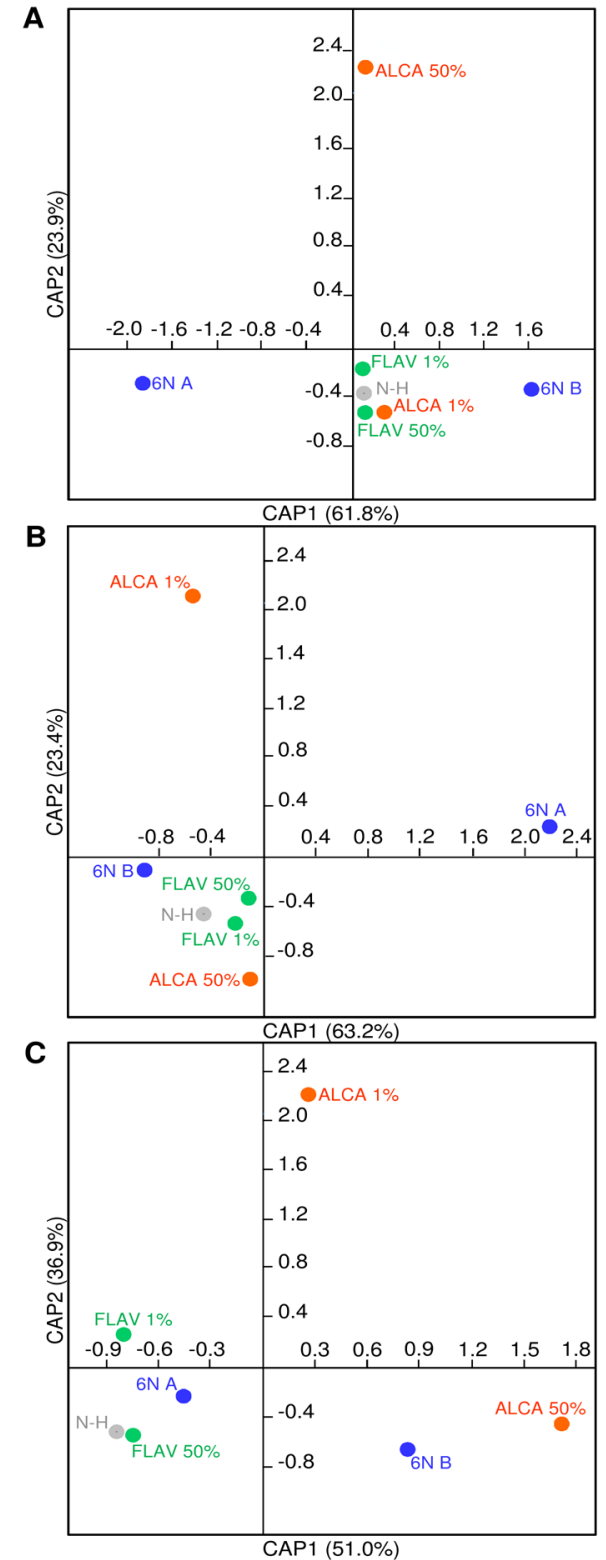

Figure 4: Principal component analysis (PCA) of hydrolysed samples according to their peptide composition. PCA was obtained for soybean (A), rapeseed (B) and guar $(C)$ samples using data for non-hydrolysed samples $(\mathrm{N}-\mathrm{H}$; grey), acid hydrolysates (blue) obtained by incubation with $6 \mathrm{~N} \mathrm{H}_{2} \mathrm{SO}_{4}$ at $121^{\circ} \mathrm{C}$ for $15 \mathrm{~min}(6 \mathrm{~N}$ A) or at $100^{\circ} \mathrm{C}$ for $8 \mathrm{~h}(6 \mathrm{~N} \mathrm{~B})$, and enzymatic hydrolysates obtained using Alcalase (ALCA, orange) and Flavourzyme (FLAV, green) at a dosage of $1 \%$ (ALCA 1\% and FLAV $1 \%$, respectively) or $50 \%$ of the protein content (ALCA $50 \%$ and FLAV $50 \%$, respectively). The two first principal components are plotted with the proportion of variance explained by each component in brackets.

proved to be involved in triggering and amplifying plant immunity [11]. Likewise, artificial protein hydrolysates were demonstrated to act as resistance inducers [25-27] and their biocontrol activity was affected by the original protein source, hydrolysis method and degree of hydrolysis $[20,28]$, as well as by their biochemical properties $[18,56]$. On the basis of these findings, we investigated and compared the impact of different plant protein sources and different hydrolysis methods on the efficacy of protein hydrolysates in controlling courgette powdery mildew, in order to clarify the possible role of specific peptide fragments and amino acids 
Citation: Cappelletti M, Perazzolli M, Nesler A, Giovannini O, Pertot I (2017) The Effect of Hydrolysis and Protein Source on the Efficacy of Protein Hydrolysates as Plant Resistance Inducers against Powdery Mildew. J Bioprocess Biotech 7: 306. doi:10.4172/2155-9821.1000306

Page 7 of 10

\begin{tabular}{|c|c|c|c|c|c|}
\hline \multirow{2}{*}{ Peptide number } & \multirow{2}{*}{ Peptide sequences } & \multicolumn{2}{|c|}{ Enzymatic hydrolysates } & \multicolumn{2}{|c|}{ Acid hydrolysates } \\
\hline & & $\mathbf{R}^{2}$ value & $p$-value & $\mathbf{R}^{2}$ value & $p$-value \\
\hline 1 & EWVDSAGAGAGGGGAPGTDFVSCVGK & -0.348 & 0.028 & -0.082 & NS \\
\hline 2 & GGTGGAQLPGRDGMLVAYAPALVAAAASVVPGAVEGLR & -0.042 & NS & 0.729 & 0.000 \\
\hline 3 & HEGSPGAAEGQGADQQGGGLAVAAAGEPDGDGDGGVRR & -0.068 & NS & -0.707 & 0.000 \\
\hline 4 & ISASGVVVAPPPPPPPPPPPPPPHLK & - & - & 0.071 & NS \\
\hline 5 & TNHRFSEIEIDMISLNVIEVFPAIQQSLI & - & - & 0.561 & 0.001 \\
\hline 6 & QKIGGGGGGGGGGGGGGGGGPPK & 0.108 & NS & - & - \\
\hline 7 & IGGGGGGGGGGGGGGGGGPPK & 0.108 & NS & - & - \\
\hline 8 & TTTMALAGAAAGMGKGNGLSSSSMHSVAR & 0.108 & NS & - & - \\
\hline 9 & FYGSGEGGMPGGMPGAGGPGGFPGAGGPAGGHGGDDGPTVEEVD & 0.170 & NS & - & - \\
\hline 10 & EGAGAGAAAATTGGAAAAR & 0.170 & NS & - & - \\
\hline 11 & MGGGHHDMGGMAMAPPPAAAAAAAHGGNK & 0.084 & NS & - & - \\
\hline 12 & SVDDLIMNVGSGGGGAPMAVATTAGGGDAGGTPPHFSFTR & -0.013 & NS & - & - \\
\hline 13 & ELIGGGGGGGGCC & -0.013 & NS & - & - \\
\hline
\end{tabular}

Pearson's correlation analysis between efficacy values (\%) against powdery mildew and quantitation ratios of peptides detected in enzymatic and acid hydrolysates of the guar meal was performed on all replicates (plotted plants). Correlation ( $R^{2}$ value) and significant ( $p$-value $\left.\leq 0.05\right)$ or non-significant (NS) values were calculated.

Table 2: Pearson's correlation between the efficacy against powdery mildew and the quantitation ratios of peptides detected in guar enzymatic and acid hydrolysates.

\begin{tabular}{|c|c|c|c|c|}
\hline \multirow{2}{*}{ Amino acid } & \multicolumn{2}{|c|}{ Enzymatic hydrolysate } & \multicolumn{2}{|c|}{ Acid hydrolysate } \\
\hline & $\mathbf{R}^{2}$ value & $p$-value & $\mathbf{R}^{2}$ value & $p$-value \\
\hline L-Glicine & 0.214 & NS & 0.468 & 0.007 \\
\hline L-Alanine & 0.210 & NS & 0.481 & 0.005 \\
\hline L-Proline & 0.169 & NS & 0.598 & 0.000 \\
\hline L-Threonine & 0.222 & NS & 0.381 & 0.031 \\
\hline L-Leucine/lsoleucine & 0.107 & NS & 0.317 & NS \\
\hline L-Histidine & 0.190 & NS & 0.733 & 0.000 \\
\hline L-Aspartic acid & -0.0181 & NS & 0.169 & NS \\
\hline L-Arginine & 0.235 & NS & 0.559 & 0.001 \\
\hline DL-Homophenylalanine & 0.318 & 0.046 & 0.750 & 0.000 \\
\hline L-Aspartic acid & 0.195 & NS & 0.668 & 0.000 \\
\hline L-Cysteine & 0.287 & NS & 0.422 & 0.016 \\
\hline L-Glutamic acid & 0.217 & NS & 0.755 & 0.000 \\
\hline L-Glutamine & 0.351 & 0.026 & 0.686 & 0.000 \\
\hline L-Lysine & 0.211 & NS & 0.658 & 0.000 \\
\hline L-Methionine & 0.204 & NS & 0.078 & NS \\
\hline L-Phenylalanine & 0.309 & NS & 0.742 & 0.000 \\
\hline L-Serine & 0.186 & NS & 0.756 & 0.000 \\
\hline L-Valine & 0.285 & NS & 0.593 & 0.000 \\
\hline Glycated L-Lysine & 0.204 & NS & 0.603 & 0.000 \\
\hline Glycated L-Arginine & - & - & 0.561 & 0.001 \\
\hline
\end{tabular}

Pearson's correlation analysis between efficacy values (\%) against powdery mildew and free amino acid concentrations $(\mu \mathrm{g} / \mathrm{mL}) \mathrm{was}$ performed on all replicates (plotted plants) for enzymatic and acid hydrolysates of the guar meal. Correlation ( $R^{2}$ value) and significant ( $p$-value $\left.\leq 0.05\right)$ or non-significant (NS) values were calculated

Table 3: Pearson's correlation between the efficacy against powdery mildew and the free amino acid concentrations of guar enzymatic and acid hydrolysates.

in the induction of resistance.

Our results showed that both enzymatic and acid methods significantly enhanced the efficacy of guar against courgette powdery mildew, in particular when hydrolysis was carried out with Alcalase $50 \%$ and with $\mathrm{H}_{2} \mathrm{SO}_{4} 6 \mathrm{~N}$ condition $\mathrm{B}$, respectively. Conversely, the biocontrol activity of soybean and rapeseed protein sources against courgette powdery mildew was not improved by the tested hydrolysis processes. In agreement with previous findings [57], our results confirmed that the extent to which the functional properties of a protein may be altered by hydrolysis is very much dependent on the degree to which the protein has been hydrolysed. Indeed, a positive correlation was found between efficacy and the DH values of guar acid hydrolysates, suggesting that high hydrolysis time and temperature conditions could increase the biocontrol activity of this protein source. DH affects the physicochemical characteristics of protein hydrolysates and could in turn affect their functionality [17]. Among other things, amino acid and peptide compositions were proved to modulate the biological activity of protein 
hydrolysates [56], depending on molecular size, structure and specific sequence [18]. In particular, peptide concentrations were usually higher in enzymatically-derived protein hydrolysates than in chemicallyderived ones [14], because proteolytic enzymes, which do not need high temperature to exert their function, usually target specific peptide bonds, producing low-salted mixtures of different length peptides [14]. As a result, PCA analysis performed on the peptide composition data of each protein source highlighted major differences between enzymatic hydrolysates, while acid hydrolysates clustered with the non-hydrolysed sample. For guar enzymatic and acid hydrolysates, significant correlations were detected between efficacy values and the quantitation ratios of specific peptide sequences, suggesting their crucial role against powdery mildew. Indeed, specific peptides of plant origin have been demonstrated to act as non-toxic signalling molecules for innate plant defence [32]. More specifically, the concentrations of Peptide 2 (GGTGGAQLPGRDGMLVAYAPALVAAAASVVPGAVEGLR) and Peptide 5 (TNHRFSEIEIDMISLNVIEVFPAIQQSLI) of guar increased after acid hydrolysis and correlated with increased efficacy against powdery mildew. Thus, similar peptides found in the $6 \mathrm{~N}$ A acid sample (EMGGKGGGGGGGGGGGGGGGPG) and the $6 \mathrm{~N}$ B acid sample (DGGGGGGSGAGAVVG and TNHRFSEIEIDMISLNVIEVFPAIQQSLI) may be responsible for plant defence activation against powdery mildew, possibly by mimicking the biological activity of endogenous natural DAMPs. In particular, peptides deriving from cytosolic proteins, such as the active form of systemin [58] and the AtPep1 peptide [59], were shown to be internal signals for plant defence mechanisms in the soybean and Arabidopsis thaliana respectively. A similar function was demonstrated for peptides originating from secreted precursors, such as hydroxyproline-rich systemins in the potato [60] and phytosulphokines in A. thaliana [61]. Furthermore, several peptides released from the degradation of proteins with primary functions were shown to elicit plant defence responses, such as the inceptin family in the cowpea [62] and other peptide fragments in the soybean $[58,63]$ for example. All of them seem to be active as elicitors and can activate the expression of typical defence marker genes [11]. However, sequences of guar Peptide 2 and Peptide 5 do not have similarities with the above-mentioned peptides, previously referred to as DAMPs [11]. Conversely, guar Peptide 1 and Peptide 3 were negatively correlated to efficacy levels in enzymatic and acid hydrolysates respectively, indicating that they may interfere with the activation of plant defence. In addition, guar enzymatic hydrolysates did not affect conidia germination on leaf disks, suggesting a mode of action mainly based on the stimulation of plant resistance mechanisms, as observed for other protein extracts. Indeed, peptide fragments of different origin have been shown to elicit grapevine defence mechanisms by the up-regulation of defence-related genes [24-27]. However, further analysis will be required to demonstrate how these peptide sequences could be involved in plant immunity regulation.

Although chemical hydrolysis has several drawbacks as compared to enzymatic hydrolysis (e.g., an increase in salinity) [14,29], both methods were investigated, in order to understand whether the potential efficacy in terms of disease control was caused by the hydrolysis process itself or eventually by the use of specific enzymes. Acid hydrolysis needs high temperatures to be carried out and randomly attacks all peptide bonds, leading to a high DH and a high free amino acid content [14]. Hence, PCA of amino acid composition data highlighted the highest variability between $6 \mathrm{~N} \mathrm{~A}$ and $6 \mathrm{~N} \mathrm{~B}$ acid hydrolysates for each protein source. Interestingly, the guar hydrolysates with significant efficacy against courgette powdery mildew (Alcalase $50 \%$ and $6 \mathrm{~N} \mathrm{~B}$ ) clustered together, suggesting a similar amino acid content. A bigger difference in free amino acid composition was observed between Alcalase 1\% and 50\% hydrolysates as compared to Flavourzyme $1 \%$ and $50 \%$ samples, and the latter enzyme contains both endo- and exoprotease activities [45] For guar acid hydrolysates, positive correlations were found between efficacy values and amino acid concentrations, suggesting that they may make a contribution to efficacy against powdery mildew. Indeed, the twenty proteinogenic amino acids play essential roles in the regulation of development, growth and stress responses in plants, and previous studies have revealed the involvement of amino acid metabolism in plant disease responses [64-67]. For example, treatment of rice roots with amino acids such as glutamate induced systemic resistance against rice blast in leaves [68], and lime plants treated with methionine significantly increased plant-induced resistance against citrus cancer disease [69]. Interestingly, positive correlations were also found for rapeseed acid hydrolysates, indicating that amino acids could partially improve the biocontrol characteristics of hydrolysates against courgette powdery mildew under greenhouse conditions. In addition to amino acids and peptides, plant protein hydrolysates contain other organic compounds, such as phenols, lipids and carbohydrates [14], which have been shown to act as active signals of defence responses. Specifically, phenolic compounds are quickly synthesised at the infection site, resulting in the effective isolation of the pathogen [70,71], and likewise lipids [72,73] and carbohydrates [74] have been demonstrated to be involved in plant immunity. Conversely, animal-derived protein hydrolysates lack carbohydrates, phenols and phytohormones [14], and repeated foliar applications caused phytotoxic effects on plant growth [30] that could be attributed to an unbalanced amino acid composition [31] and a high salinity [23]. Moreover, European Regulation 354/2014 recently prohibited the application of these products to the edible parts of organic crops, because their use generates serious concerns in terms of food safety.

Our results demonstrate that the biocontrol activity of protein hydrolysates against the powdery mildew of courgettes is affected by the original protein source, the method and the degree of hydrolysis. Moreover, free amino acid and peptide composition could contribute to efficacy levels and regulate plant responses to pathogen infection. However, the use of strong acids such as $\mathrm{H}_{2} \mathrm{SO}_{4}$ during hydrolysis caused an increase in the salinity of protein hydrolysates [14], and the formation of $\mathrm{K}_{2} \mathrm{SO}_{4}$ in guar acid hydrolysates contributed to disease control Indeed, guar acid hydrolysates significantly reduced the percentage of conidia germination on leaf disks, in contrast to enzymatic ones. Other critical aspects in acid hydrolysis are the destruction of several amino acids and other thermolabile compounds and the phenomenon called racemisation, namely the conversion of free amino acids from $\mathrm{L}$-form to D-form, which cannot be used by plants in their metabolism, making the hydrolysate less effective or even potentially phytotoxic $[29,14]$.

The possibility of controlling crop diseases with the foliar application of low-cost protein hydrolysates represents an innovative approach, especially with a view to reducing pesticides in integrated pest management programs. Our results indicate the efficacy of guar protein hydrolysates against courgette powdery mildew, and two specific hydrolysis methods led to the formation of bioactive products. Preventive foliar application of plant-derived industrial by-products may offer considerable environmental and economic benefits. However, if expensive commercial enzymes need to be used in the hydrolysis process, the economic advantages of using agricultural by-products (such as protein meal deriving from oil extraction) may be nullified. Furthermore, knowledge of the application of protein hydrolysates to crops is far from being complete and further studies are required, in order to fully clarify their mechanisms of action and the effects on phyllosphere microbial communities. 
Citation: Cappelletti M, Perazzolli M, Nesler A, Giovannini O, Pertot I (2017) The Effect of Hydrolysis and Protein Source on the Efficacy of Protein Hydrolysates as Plant Resistance Inducers against Powdery Mildew. J Bioprocess Biotech 7: 306. doi:10.4172/2155-9821.1000306

\section{Acknowledgements}

We thank Franca Valentini for providing technical support with the courgette plants, and Carmela Sicher and Livia Zanotelli for helping with the conidia germination experiments.

\section{Funding}

This project has received funding from the European Union's Seventh Framework Programme for research, technological development and demonstration under grant agreement no. 324416 (project INNOVA, theme FP7PEOPLE-2012-IAPP) and from the European Union's Horizon 2020 research and innovation programme under the Marie Skłodowska-Curie grant agreement no. 722642 (project INTERFUTURE).

\section{Author Contributions}

Conceived and designed the experiments: MC, MP, IP. Carried out the experiments and acquired the data: MC AN OG. Analysed the data: MC. Wrote the manuscript: MC. Revised the manuscript: MP AN OG IP. All authors have read the manuscript and agree with its content.

\section{Conflict of Interest}

The authors declare that they have no conflict of interest

\section{References}

1. Fantke $P$, Friedrich $R$, Jolliet $O$ (2012) Health impact and damage cost assessment of pesticides in Europe. Environ Int 49: 9-17.

2. Hillocks RJ (2012) Farming with fewer pesticides: EU pesticide review and resulting challenges for UK agriculture. Crop Prot 31: 85-93.

3. Skevas T, Lansink A, Stefanou SE (2013) Designing the emerging EU pesticide policy: a literature review. Njas Wagen J Life Sc 64-65: 95-103.

4. Delaunois B, Farace G, Jeandet P, Clement C, Baillieul F, et al. (2014) Elicitors as alternative strategy to pesticides in grapevine? Current knowledge on their mode of action from controlled conditions to vineyard. Environ Sci Pollut R 21 : 4837-4846.

5. Jones JDG, Dangl JL (2006) The plant immune system. Nature 444: 323-329.

6. Boller T, Felix G (2009) A renaissance of elicitors: perception of microbeassociated molecular patterns and danger signals by pattern-recognition receptors. Annu Rev Plant Biol 60: 379-406.

7. Wu S, Shan L, He P (2014) Microbial signature-triggered plant defense responses and early signaling mechanisms. Plant Sci 228: 118-126.

8. Pieterse CMJ, Leon-Reyes A, Van der Ent S, Van Wees SCM (2009) Networking by small-molecule hormones in plant immunity. Nat Chem Biol 5: 308-316.

9. Walters DR, Ratsep J, Havis ND (2013) Controlling crop diseases using induced resistance: challenges for the future. J Exp Bot 64: 1263-1280.

10. Van Wees SCM, Van der Ent S, Pieterse CMJ (2008) Plant immune responses triggered by beneficial microbes. Curr Opin Plant Biol 11: 443-448.

11. Albert M (2013) Peptides as triggers of plant defence. J Exp Bot 64: 5269-5279.

12. Yamaguchi $Y$, Huffaker $A$ (2011) Endogenous peptide elicitors in higher plants. Curr Opin Plant Biol 14: 351-357.

13. Calvo P, Nelson L, Kloepper JW (2014) Agricultural uses of plant biostimulants Plant Soil 383: 3-41.

14. Colla G, Nardi S, Cardarelli M, Ertani A, Lucini L, et al. (2015) Protein hydrolysates as biostimulants in horticulture. Sci Hortic 196: 28-38.

15. Sinha R, Radha C, Prakash J, Kaul P (2007) Whey protein hydrolysate: functional properties, nutritional quality and utilization in beverage formulation. Food Chem 101: 1484-1491.

16. Panyam D, Kilara A (1996) Enhancing the functionality of food proteins by enzymatic modification. Trends Food Sci Tech 7: 120-125.

17. Mahmoud MI (1994) Physicochemical and functional-properties of protein hydrolysates in nutritional products. Food Technol 48: 89-95.

18. Chabanon G, Chevalot I, Framboisier X, Chenu S, Marc I (2007) Hydrolysis of rapeseed protein isolates: kinetics, characterization and functional properties of hydrolysates. Process Biochem 42: 1419-1428.

19. Adler-Nissen J (1982) Limited enzymic degradation of proteins: a new approach in the industrial application of hydrolases. J Chem Technol Biotechnol 32: 138-156.

20. Cheison SC, Zhang SB, Wang Z, Xu SY (2009) Comparison of a modified spectrophotometric and the $\mathrm{pH}$-stat methods for determination of the degree of hydrolysis of whey proteins hydrolysed in a tangential-flow filter membrane reactor. Food Res Int 42: 91-97.
21. Stiegler JC, Richardson MD, Karcher DE, Roberts TL, Norman RJ (2013) Foliar absorption of various inorganic and organic nitrogen sources by creeping bentgrass. Crop Sci 53: 1148-1152.

22. du Jardin P (2015) Plant biostimulants: definition, concept, main categories and regulation. Sci Hortic 196: 3-14.

23. Colla G, Rouphael Y, Canaguier R, Svecova E, Cardarelli M (2014) Biostimulan action of a plant-derived protein hydrolysate produced through enzymatic hydrolysis. Front Plant Sci 5: 448.

24. Lachhab N, Sanzani SM, Adrian M, Chiltz A, Balacey S, et al. (2014) Soybean and casein hydrolysates induce grapevine immune responses and resistance against Plasmopara viticola. Front Plant Sci 5: 716

25. Lachhab N, Sanzani SM, Bahouaoui MA, Boselli M, Ippolito A (2016) Effect of some protein hydrolysates against gray mould of table and wine grapes. Eur $\mathrm{J}$ Plant Pathol 144: 821-830.

26. Nesler A, Perazzolli M, Puopolo G, Giovannini O, Elad Y, et al. (2015) A complex protein derivative acts as biogenic elicitor of grapevine resistance against powdery mildew under field conditions. Front Plant Sci 6: 715

27. Cappelletti M, Perazzolli M, Antonielli L, Nesler A, Torboli E, et al. (2016) Lea treatments with a protein-based resistance inducer partially modify phyllosphere microbial communities of grapevine. Front Plant Sci 7: 1053.

28. Pecha J, Fuerst T, Kolomaznik K, Friebrova V, Svoboda P (2012) Protein biostimulant foliar uptake modeling: the impact of climatic conditions. AIChE J 58: 2010-2019.

29. Lisiecka J, Knaflewski M, Spizewski T, Fraszczak B, Kałuzewicz A, et al. (2011) The effect of animal protein hydrolysate on quantity and quality of strawberry daughter plants cv. 'Elsanta'. Acta Sci Pol-Hortoru 10: 31-40.

30. Cerdan M, Sanchez-Sanchez A, Oliver M, Juarez M, Sanchez-Andreu JJ (2009) Effect of foliar and root applications of amino acids on iron uptake by tomato plants. Acta Hortic 830: 481-488.

31. Oaks A, Aslam M, Boesel I (1977) Ammonium and amino-acids as regulators of nitrate reductase in corn roots. Plant Physiol 59: 391-394.

32. Ryan CA, Pearce G, Scheer J, Moura DS (2002) Polypeptide hormones. Plant Cell 14: S251-S264.

33. Day L (2013) Proteins from land plants - Potential resources for human nutrition and food security. Trends Food Sci Tech 32: 25-42.

34. Nidhina N, Muthukumar SP (2015) Antinutritional factors and functionality of protein-rich fractions of industrial guar meal as affected by heat processing. Food Chem 173: 920-926.

35. Wickramasuriya SS, Yi YJ, Yoo J, Kang NK, Heo JM (2015) A review of canola meal as an alternative feed ingredient for ducks. J Anim Sci Technol 57: 1-9.

36. Grasser LA, Fadel JG, Garnett I, Depeters EJ (1995) Quantity and economic importance of nine selected by-products used in california dairy rations. J Dairy Sci 78: 962-971.

37. Perez-Garcia A, Romero D, Fernandez-Ortuno D, Lopez-Ruiz F, De Vicente A, et al. (2009) The powdery mildew fungus Podosphaera fusca (synonym Podosphaera xanthii), a constant threat to cucurbits. Mol Plant Pathol 10: 153 160.

38. Mucharromah E, Kuc J (1991) Oxalate and phosphates induce systemic resistance against diseases caused by fungi, bacteria and viruses in cucumber. Crop Prot 10: 265-270.

39. Reuveni M, Agapov V, Reuveni R (1993) Induction of systemic resistance to powdery mildew and growth increase in cucumber by phosphates. Biol Agric Hortic 9: 305-315

40. Reuveni R, Dor G, Raviv M, Reuveni M, Tuzun S (2000) Systemic resistance against Sphaerotheca fuliginea in cucumber plants exposed to phosphate in hydroponics system, and its control by foliar spray of mono-potassium phosphate. Crop Prot 19: 355-361.

41. van Aubel G, Buonatesta R, Van Cutsem P (2014) COS-OGA: A nove oligosaccharidic elicitor that protects grapes and cucumbers against powdery mildew. Crop Protection 65: 129-137.

42. He R, Girgih AT, Malomo SA, Ju X, Aluko RE (2013) Antioxidant activities of enzymatic rapeseed protein hydrolysates and the membrane ultrafiltration fractions. J Funct Foods 5: 219-227.

43. Nadtochii L, Zabodalova L, Domoroshchenkova M (2015) Development of cheese product with hydrolyzed soybean emulsion. Agron Res 13: 1010-1019.

44. Peña-Ramos EA, Xiong YL (2002) Antioxidant activity of soy protein hydrolysates in a liposomal system. J Food Sci 67: 2952-2956.

45. Merz M, Eisele T, Berends P, Appel D, Rabe S, et al. (2015) Flavourzyme, an enzyme preparation with industrial relevance: automated nine-step purification and partial characterization of eight enzymes. J Agric Food Chem 63: 5682-5693. 
Citation: Cappelletti M, Perazzolli M, Nesler A, Giovannini O, Pertot I (2017) The Effect of Hydrolysis and Protein Source on the Efficacy of Protein Hydrolysates as Plant Resistance Inducers against Powdery Mildew. J Bioprocess Biotech 7: 306. doi:10.4172/2155-9821.1000306

46. Aaslyng MD, Elmore JS, Mottram DS (1998) Comparison of the aroma characteristics of acid-hydrolyzed and enzyme-hydrolyzed vegetable proteins produced from soy. J Agric Food Chem 46: 5225-5231.

47. Zorb C, Senbayram M, Peiter E (2014) Potassium in agriculture - status and perspectives. J Plant Physiol 171: 656-669.

48. Nielsen PM, Petersen D, Dambmann C (2001) Improved method for determining food protein degree of hydrolysis. J Food Sci 66: 642-646.

49. Church FC, Swaisgood HE, Porter DH, Catignani GL (1983) Spectrophotometric assay using o-phthaldialdehyde for determination of proteolysis in milk and isolated milk proteins. J Dairy Sci 66: 1219-1227.

50. Adler-Nissen J (1986) Enzymic hydrolysis of food proteins. Elsevier Applied Science Publishers, New York.

51. Simonian MH (2004) Spectrophotometric determination of protein concentration. Current Protocols in Toxicology, Mahin D Maines, Appendix 3: 1-7.

52. EPPO (1990) EPPO Bullettin: Guideline for the biological evaluation of fungicides: powdery mildews on cucurbits and other vegetables 20: 451-463.

53. Romero D, De Vicente A, Olmos JL, Dávila JC, Pérez-García A (2007) Effect of lipopeptides of antagonistic strains of Bacillus subtilis on the morphology and ultrastructure of the cucurbit fungal pathogen Podosphaera fusca. J Appl Microbiol 103: 969-976

54. Peries OS (1962) Studies on strawberry mildew, caused by Sphaerotheca macularis (Wallr. ex Fries) Jaczewski. Ann Appl Biol 50: 211-224.

55. Pertot I, Fiamingo F, Amsalem L, Maymon M, Freeman S, et al. (2007) Sensitivity of two Podosphaera aphanis populations to disease control agents. J Plant Pathol 89: 85-96

56. Jamdar SN, Rajalakshmi V, Pednekar MD, Juan F, Yardi V, et al. (2010) Influence of degree of hydrolysis on functional properties, antioxidant activity and ACE inhibitory activity of peanut protein hydrolysate. Food Chem 121: 178184.

57. Spellman D, McEvoy E, O'Cuinn G, FitzGerald RJ (2003) Proteinase and exopeptidase hydrolysis of whey protein: comparison of the TNBS, OPA and $\mathrm{pH}$ stat methods for quantification of degree of hydrolysis. Int Dairy J 13: 447-453.

58. Pearce G, Yamaguchi Y, Barona G, Ryan CA (2010) A subtilisin-like protein from soybean contains an embedded, cryptic signal that activates defenserelated genes. Proc Natl Acad Sci U S A 107: 14921-14925.

59. Huffaker A, Pearce G, Ryan CA (2006) An endogenous peptide signal in Arabidopsis activates components of the innate immune response. Proc Nat Acad Sci USA 103: 10098-10103.
60. Bhattacharya R, Koramutla MK, Negi M, Pearce G, Ryan CA (2013) Hydroxyproline-rich glycopeptide signals in potato elicit signalling associated with defense against insects and pathogens. Plant Sci 207: 88-97.

61. Igarashi D, Tsuda K, Katagiri F (2012) The peptide growth factor, phytosulfokine, attenuates pattern-triggered immunity. Plant J 71: 194-204.

62. Schmelz EA, LeClere S, Carroll MJ, Alborn HT, Teal PEA (2007) Cowpea chloroplastic ATP synthase is the source of multiple plant defense elicitors during insect herbivory. Plant Physiol 144: 793-805.

63. Yamaguchi Y, Barona G, Ryan CA, Pearce G (2011) GmPep914, an eightamino acid peptide isolated from soybean leaves, activates defense-related genes. Plant Physiol 156: 932-942.

64. Scheideler M, Schlaich NL, Fellenberg K, Beissbarth T, Hauser NC, et al. (2002) Monitoring the switch from housekeeping to pathogen defense metabolism in Arabidopsis thaliana using cDNA arrays. J Biol Chem 277: 10555-10561.

65. Ward JL, Forcat S, Beckmann M, Bennett M, Miller SJ, et al. (2010) The metabolic transition during disease following infection of Arabidopsis thaliana by Pseudomonas syringae pv. tomato. Plant J 63: 443-457.

66. Liu G, Ji Y, Bhuiyan NH, Pilot G, Selvaraj G, et al. (2010) Amino acid homeostasis modulates salicylic acid-associated redox status and defense responses in Arabidopsis. Plant Cell 22: 3845-3863.

67. Cecchini NM, Monteoliva MI, Alvarez ME (2011) Proline dehydrogenase contributes to pathogen defense in Arabidopsis. Plant Physiol 155: 1947-1959.

68. Kadotani N, Akagi A, Takatsuji H, Miwa T, Igarashi D (2016) Exogenous proteinogenic amino acids induce systemic resistance in rice. Bmc Plant Biology 16: 60

69. Hasabi V, Askari H, Alavi SM, Zamanizadeh H (2014) Effect of amino acid application on induced resistance against citrus canker disease in lime plants. J Plant Prot Res 54: 144-149.

70. Lattanzio V, Lattanzio VMT, Cardinali A (2006) Role of phenolics in the resistance mechanisms of plants against fungal pathogens and insects. In: Imperato F (ed) Phytochemistry: Advances in research 23-67.

71. Nicholson RL, Hammerschmidt R (1992) Phenolic-compounds and their role in disease resistance. Annu Rev Phytopathol 30: 369-389.

72. Shah J (2005) Lipids, lipases, and lipid-modifying enzymes in plant disease resistance. Annu Rev Phytopathol 43: 229-260.

73. Hoffmann-Benning S (2015) Transport and function of lipids in the plant phloem

74. Trouvelot S, Héloir MC, Poinssot B, Gauthier A, Paris F, et al. (2014) Carbohydrates in plant immunity and plant protection: roles and potential application as foliar sprays. Front Plant Sci 5: 592. 